\title{
An important agent in gastroenteritis: Campylobacter
}

\author{
Yesim Gurol $^{1 *}$, Zehra Kipritci ${ }^{1}$, Gülden Celik ${ }^{1}$ \\ ${ }^{1}$ Yeditepe University Department of Clinical Microbiology, Istanbul, Turkey
}

$C$ ampylobacter infections are common in both developed and developing countries. The reported incidence of culture confirmed infections shows variability among countries due to culturing procedures. (1). Here we report laboratory-based surveillance data collected between 2013 and 2015 in Yeditepe University Hospital Microbiology Laboratory. Among 2807 feces cultures, Salmonella spp. $(n=135)$, Campylobacter spp. $(n=118)$, Aeromonas spp. $(n=6)$ and Shigella spp. $(n=3)$, isolates were detected. Out of 118 Campylobacter spp. isolates, the distribution was as follows: $C$. jejuni $(\mathrm{n}=101), C$. upsaliensis $(\mathrm{n}=8), C$. coli $(n=6)$ and other species $(n=3)$.

The fecal samples were cultured in Campylobacter-BAP medium (Salubris, Turkey) and incubated under microaerophilic conditions (CampyGen, Oxoid, UK) at $42^{\circ} \mathrm{C}$ for 48 hours. Suspected colonies were examined by Gram stain and evaluated for oxidase and catalase positivity; and then were first confirmed by Campylobacter latex agglutination test (Dryspot, Oxoid, UK).

They were identified by API CAMPY biochemical identification system (BioMérieux, France). Antimicrobial susceptibility of isolates against erythromycin was also tested with API CAMPY system (BioMérieux, France); ciprofloxacin and gentamicin susceptibilies were tested by E-test (bioMérieux, France).

The distribution of isolates, demographic information and seasonal epidemiology in patients with
Campylobacter positive cultures are shown. It seems there is no definite season for campylobacteriosis. We mostly isolate from the pediatric patients. (Table 1, Figure 1) Beyond detecting difficulties by culture, antibiotic resistance becomes a problem. In the EFSA/ECDC report 2013, the highest frequency of resistance was observed for nalidixic acid (47.8\%) and ciprofloxacin (44.4\%) followed by ampicillin (35.3\%) and tetracycline $(30.5 \%)$; low resistance levels were observed to erythromycin (3.5\%) and gentamicin (0.4\%). According to FDA/CDC/UDSA Report 2013 resistance to tetracycline was most common (45.9\%), followed by ciprofloxacin $23.5 \%$ in $C$. jejuni and $35.8 \%$ in $C$. coli). Macrolide resistance was observed in $1.7 \%-2.7 \%(2)$.

*Corresponding Author: Yesim Gurol. Hastane yolu caddesi İcerenkoy mahhalesi, 34752 Atasehir, Istanbul, Turkey. Tel: +90 2165784000 E-mail: dryesimg@gmail.com Received: Aug 01, 2016. Accepted: Jan 22, 2017 Published Online: Jan 27, 2017.

This is an Open Access article distributed under the terms of the Creative Commons Attribution Non-Commercial License (http://creativecommons.org/licenses/bync/4.0/) which permits unrestricted non-commercial use, distribution, and reproduction in any medium, provided the original work is properly cited. 
During the study period, our resistance rates were detected as $13 \%$ for erythromycin, $11 \%$ for ciprofloxacin. It seems a slight increase in erythromycin resistance in our strains comparing to 2009-2012 rates (from 7\% to 13\%) (3). No resistance was seen in gentamicin. Fecal culture procedures should be applied in our routine laboratories to see the surveillance of Campylobacteriosis and find our national rate in resistance to antibiotics.

Contributions: The authors contributed equally.

Ethics Committee Approval: N.A.

Informed Consent: Written informed consent was obtained from patients who participated in this study.

Peer-review: Externally peer-reviewed.

Conflict of Interest: No conflict of interest was declared by the author.

Financial Disclosure: The author declared that this study has received no financial support.

\section{References}

1. Fitzgerald C, Nachamkin I: Campylobacter and Arcobacter. In: Manual of Clinical Microbiology. Volume 1. 11th ed. Washington, ASM Press, 2015: 998.

2. Gea B, Wanga F, Sjölund-Karlssonc M, McDermott PF. Antimicrobial resistance in Campylobacter: Susceptibility testing methods and resistance trends. Journal of Microbiological Methods 2013; 95: 57-67.

3. Gurol Y, Kipritçi Z, Biçer S, Acuner İÇ, Vitrinel A, Çelik G. Campylobacter data from a Turkish University Hospital Laboratory. Acta Gastro-Enterologica Belgica Vol LXXVI, April-June 2013.
How to cite?

Gurol Y, Kipritci Z, Celik G. An important agent in gastroenteritis: Campylobacter. J Immunol Clin Microbiol 2016; 1(3).

DOI: http://dx.doi.org/10.5455/ jicm.20.20170122

Submit your next manuscript to the JICM and take full advantage of:

- Convenient online submission,

- Thorough peer review, Fast Response,

- No charges,

- Immediate publication on acceptance,

- Inclusion in Scopemed and High quality indexes,

- Research which is freely available for redistribution of the worldwide literature

To submit your manuscript, click on http://www.jiacm.com

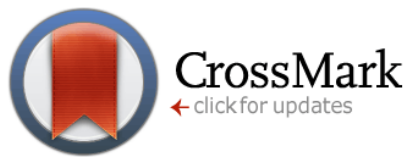

Published by The QMEL.org International Medical Education Library

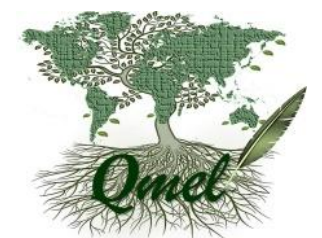

